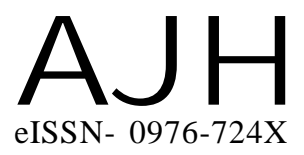

Article history :

Received : 18.06.2014

Revised : 02.11.2014

Accepted : 16.11.2014

Members of the Research Forum

Associated Authors:

Department of Horticulture, Faculty of Agriculture, Annamalai University, ANNAMALAI NAGAR (T.N.) INDIA

Email : manihort@yahoo.co.in,

rameshflora@yahoo.com
Author for correspondence : KEISAM PRADEEP

Department of Horticulture, Faculty of

Agriculture, Annamalai University,

ANNAMALAI NAGAR (T.N.) INDIA

Email : keisampradeep@gmail.com
THE ASIAN JOURNAL OF HORTICULTURE

Volume 9 | Issue 2 | Dec., 2014 |416-420

Visit us -www.researchjournal.co.in
A

RESEARCH PAPER

DOI : 10.15740/HAS/TAJH/9.2/416-420

\title{
Effect of organic nutrients on growth, flowering and yield of Gladiolus grandiflorus L.
}

\section{KEISAM PRADEEP, K. MANIVANNAN ${ }^{1}$ AND S. RAMESH KUMAR ${ }^{1}$}

ABSTRACT : The present study was laid out in RBD with three replications. Various organic fertilizers viz., farm yard manure (FYM) @ $7.5 \mathrm{t} \mathrm{ha}^{-1}$, leaf mould compost @ $7.5 \mathrm{t} \mathrm{ha}^{-1}$, vermicompost (VC) @ $2.5 \mathrm{t} \mathrm{ha}^{-1}$, humic acid (HA) @ 0.2 per cent (FS), VAM and inorganic fertilizer (RDF 100:50:150 NPK $\mathrm{kg} \mathrm{ha}^{-1}$ ) were applied. The growth and yield parameters were studied at different stages of crop growth. The study revealed that the growth characters viz., plant height, at 30 and 45 DAP, number of leaves, leaf length, leaf width and days taken for sixth leaf stage were significantly influenced by the application of organic fertilizers $\mathrm{T}_{9}$ [Vermicompost @ $2.5 \mathrm{t} \mathrm{ha}^{-1}+\mathrm{VAM}+$ humic acid @ $0.2 \%$ (FS)] registered the maximum plant height $(73.66 \mathrm{~cm}$ and $104.84 \mathrm{~cm})$ at 30 and 45 DAP, respectively, number of leaves (5.60), leaf length $(50.03 \mathrm{~cm})$, leaf width $(8.62 \mathrm{~cm})$ and minimum days taken for sixth leaf stage (37.10) were recorded. Flowering characters like minimum days taken for first spike emergence (44.10), days taken for first flower to open (51.35) and maximum spike length $(110.60 \mathrm{~cm})$, rachis length $(44.20 \mathrm{~cm})$, number of florets per spike (11.40), flower weight $(4.99 \mathrm{~g})$ and the number of marketable spike per plot (50.45) were also recorded in $\mathrm{T}_{9}$. The above treatment also recorded longer vase life (12.66 days). From the above experiment, it may be judged that, the application of vermicompost @ $2.5 \mathrm{t} \mathrm{ha}^{-1}+\mathrm{VAM}+$ humic acid @ 0.2 per cent (FS) enhanced the growth, flowering and yield of gladiolus.

KEY WORDS : Humic acid, Vermicompost, VAM(Vesicular arbuscular mycorrhizae), FYM, Gladiuolus

HOW TO CITE THIS ARTICLE : Pradeep, Keisam, Manivannan, K. and Kumar, S. Ramesh (2014). Effect of organic nutrients on growth, flowering and yield of Gladiolus grandiflorus L. Asian J. Hort., 9(2) : 416-420. 